DOI: 10.17516/1997-1370-0501

УДК 39

\title{
Development of the Sub-Ethnic Group of the Yessei Yakuts: Landscape, History, Memory
}

\author{
Ekaterina N. Romanova and Ekaterina M. Kuznetsova* \\ Institute for Humanitarian Research \\ and Indigenous Peoples of the North SB RAS \\ Yakutsk, Republic of Sakha, Russian Federation
}

Received 10.09.2019, received in revised form 16.10.2019, accepted 27.12.2019

\begin{abstract}
The article presents the development of the sub-ethnic group of the Yessei Yakuts in the aspects of landscape, history, and memory. The research is dedicated to the studies of the peripheral ethno-local group of the Yessei Yakuts, resident in the compact area by Yessei lake of the Krasnoyarsk Territory (Krai) since the $18^{\text {th }}$ century. Based on the field research data, the methods of survey, mapping, and deep interview are implemented; the previously unpublished archive materials and narrative materials are introduced into the research discourse.
\end{abstract}

Keywords: mainstream and local cultures, the Yessei Yakuts, cultural border zone, landscape, historical

Research area: ethnography, ethnology, anthropology.

Citation: Romanova, E.N., Kuznetsova, E.M. (2019). Development of the sub-ethnic Group of the Yessei Yakuts: landscape, history, memory. J. Sib. Fed. Univ. Humanit. Soc. Sci., 15(4), 453-466. DOI: $10.17516 / 1997-1370-0501$

The ethno-dialect studies intended to contribute into the research of the adaptation mechanisms and local cultures of the Turks and Tungus of the Extreme North of Russia are of great interest for today's science, as the subject matter of such research is the unique resilience experience of the indigenous peoples of the North, Siberia and the Far East. These regions play a significant role in the further sustainable development of the country as a whole due to the abundant natural resources on one hand, and conservation of the traditional ethnical culture forms, demonstrating a high level of adaptivity to the natural and climatic conditions along with the developed cultural and environmental balance in their habitat on the other hand. The studies of the ethnocultural landscape as a way of adaptation of the ethnical traditions of the indigenous peoples of the North-East Siberia, carried out with the purpose to conserve the traditional spiritual values and lifestyle in the current economic and sociocultural transformations make up a very important task of the modern humanitarian science.

(C) Siberian Federal University. All rights reserved

* Corresponding author E-mail address: e_romanova@mail.ru, kem207@mail.ru 
As a result of their economic and cultural activity, the Yakuts, representing the mainstream culture, have explored a vast land stretching from the Arctic Ocean to Chukotka and the Magadan Oblast in the east to the south-east of the Khabarovsk Krai, to the south of the Amur and Transbaikal Territories, to the Irkutsk Oblast and the Krasnoyarsk Krai in the north-west. According to A.V. Golovnev, "a mainstream culture is a mechanism of acquiring the vast spaces and synthesizing local cultures into complex communities. A special category of activity and mentality of a mainstream culture is a journey" (Golovnev, 2009: 22-23).

Elaborating on this issue, let us appeal to the history of the Yakuts' migration to the periphery of the north-west of Siberia, where, by Yessei lake, an isolated local group of the polar reindeer-breeder Yakuts was formed, later presented by the researchers as the Yessei Yakuts.

An attempt to describe the phenomenon of the mainstream and locality based on the Yakut materials from the point of view of the ethno-geographical approach was made by a well-known ethnographer and Siberia explorer G.V. Ksenofontov. One of the underlying postulates of his concept is the connection between the landscape, ethnos, and culture. The researcher was one of the first ones to notice the effect of the natural landscape peculiarities on the Yakut ethnic groups, and to point out the Yessei Yakuts in the situation of dynamic interaction with the neighbouring peoples as a local branch of the northern reindeer-breeder Yakuts. "The Yessei Yakuts came here from the Olenyok River basin; a part of the Olenyok population, when imposed a tribute in furs by the Cossacks, migrated west and occupied the Yessei lake area, in the head of the Kotuy River" (Ksenofontov, 1937: 218). In his work titled "Uraankhay Sakhalar. Essays on the Ancient Yakut History", published in 1937, the author elaborates on the thesis of variability of the ethnic culture models due to the pattern of the activities practiced by the Yakuts who found themselves outside their original territories. The changes in the natural landscape and cultural dialogues that occurred at the cross-roads of different geographic zones and ethnic habitats, the complex processes of interaction be- tween different linguistic and ethnocultural traditions contributed to the development of the original local Yakut cultural models. The concept of memory, introduced by the researcher into the Sakha history, is of special value. In his studies, dedicated to ethnogenesis and ethnic history of the Yakuts, the central text of the collective ethnic memory is the legendary history of the nation, where the mechanisms of a "remembering culture" and a culture of remembering manifest themselves.

Memory landscapes. The "place of memory" in the mental map of the Yessei Yakuts becomes the primary form of the memory culture. The centre, where the "territorial memory" is crystallised, is the family history of the Yessei Yakuts; thus, the past is conceptualised through their genealogical code. Proceeding to the overview of the Yessei Yakut clan family names, it is important to remark that the majority of the genealogical legends describe the founders of the Yessei clans as migrants from the central and northern areas of Yakutia.

In this regard, the unpublished data collected by the folklore and dialectological expedition of the Institute of Linguistics, Literature and History by Yessei Lake from the old settlers in 1959 are of special interest. According to the memories of the 108-year-old local resident Eudokia Khristoforovna Uoday: "The first ones to come to the lake were the Yakuts... There were around 40 people, and they came here to stay. That time, in the middle of the lake a mammoth task appeared from under the water. The newcomers thought that was a treasure and tried to saw the tusk off. The ice on the lake broke and all the people drowned. Later, some more people came from Yakutsk; there was one woman with them, and one more pregnant woman. They made couples and got married, starting their families here; this was where the clans of Botulu, Ospokhtor, Betiler came from; the pregnant woman who gave birth to a daughter started the clan of Osogostookh. They were called Uoday; perhaps, due to the shorter clothes that they used to wear. The first one to come here was old Kuurin with seven Yakuts. Then, D'enahiey, the grandfather of my father was born. Then there was halchyyn Ygnnaachay, who begat Kiristipien, 
my father, and then I was born"'. The tradition of "embedding" one's personal story into the historical context of populating the Yessei surroundings by the Yakuts presents genealogy as a social memory resource, where the connection between the past and the present makes up and supports the identity of the Yessei Yakuts.

Chordu clan - Churdu family name. During the field study, the genealogical legends of the Yessei Yakuts, passed over by word of mouth by the old settlers of Yessei village, were thoroughly studied. The legend told by Eudokia Petrovna Chordu (85 years old in 2009) goes as follows: "Our Chordy clan, which has always had a big herd of deer, was almost eliminated by the Khatygin clan in a number of conflicts. Before we, the Chorduns, got "surekhtemmippit", or baptised, the times had been dark, with no law or authority. The "khosuuns", or the warriors, used the so-called "alanaa and honogos", arches and arrows, as they had no guns back then. People were massacred in families with no mercy, including the elderly and children; only young women were taken away by the enemies. The conflicts were between the Khatygins, the Mayats, the Tungus and us, the Chorduns. Back in those times, we did not have any toyons, or chiefs, or any Russian governors; all people lived the same, thriving as they could; the strongest and the smartest would be normally respected. The reason for the strife was the rich land, lakes and the grasslands, the deer and the wealth of the clans. Some clans, for some reasons, were poorer or richer than others. The strife never ceased; it continued night and day for years and years, until one clan got over another. Among the Chordu there was a noble khosun named Bolon; he was the strongest and the smartest of the clan. He had three khosun brothers; one was named Soyon, and the names of others are lost: no one mentions them anymore. One day, the youngest suddenly disappeared. Then, the Chordu got attacked by the hostile clans, who killed almost

\footnotetext{
1 Proceedings of the folklore and dialectological expedition of the Institute of Linguistics, Literature and History to Yessei Lake. Findings of N.V. Yemelyanov's team. Ethnographic records. Archive of the Institute for Humanitarian Research and Indigenous Peoples of the North SB RAS F. 5, op. 6, d. 300, pages $1-3$, in Yakut language.
}

all the people and took the deer, the women and the children away, including the khosun's wife.

Bolon survived with two old women he had been taking care of. After some time, Bolon prepared for a battle for his Chordu clan and took the road. Before the journey he had to kill the old women, as they would die of starvation after some time anyway.

Bolon followed his enemies and killed them all, but accidentally he killed his wife. After the victory, Bolon took his lost younger brother and they went home, carrying all the treasures they had taken from the enemies. On the way, Bolon suddenly got sad, as though he had had a bad feeling. He said to his younger brother: "I shouldn't have killed by clever wife. My clan will not continue from now on", and after that, the number of the Chordu decreased; we are still little in number"'.

Obviously, this legend depicts the historical events of the Yessei lake territory population and all the numerous conflicts that occurred between the Yakuts and the indigenous peoples of the Siberian north-west. Moreover, different versions of the khosun battle legend is found in the khosun epos of the reindeer breeder Yakuts. According to G.V. Ksenofontov, the main bearers of this heroic epos were the northern reindeer breeder Yakuts populating the Olenyok River basin (Ksenofontov, 1937: 264).

There is another version heard from another informer, E.P. Chordu: "From my grandparents I heard, that the Chordu clan had come from the Edigen land"3. According to the archives, the first Chordu representatives were registered in the areas adjacent to the Yessei lake surroundings. The studied records dating back to the year 1847 provide the following information: "Chordu, 17 souls, headed by their elder Yakov Shadrin, were registered as the parish of the nomad Church of the Annunciation, which served the tundra and forest tundra population between the lower Lena and the Olenyok rivers"'. B.O. Dolhikh wrote that the Chordu were sometimes considered to be the

\footnotetext{
PMA. Chordu E.P. 1926- 2017. Information as of July 2009, Yessei village.

3 PMA. Chordu E.P. 1926- 2017. Information as of July 2009, Yessei village.

4 Central State Archives of the Republic of Sakha (Yakutia). F.225-I. D-248.L.Z.
} 
"descendants of the Russian peasants or townsmen" (Dolgikh, 1946: 262-263).

Obviously, and as proven by various records, due to the decrease in the Chordu population since the mid- $19^{\text {th }}$ century, the clan was a merely administrative unit, made up by uniting the Chordu clan with some other indigenous groups.

According to the legends, collected in the lower region of the Lena, the Chordu clan, which owned a lot of deer had been almost totally eliminated by the neighbouring tribes, including the Khatagins and the Kaltagirs, even before Russians came to the area. Despite the involvement of several ethnic groups (Tungus, Samoyed) into the development of the Chordu clan, it had always been based upon the Yakut ethnos, or the reindeer breeder Yakuts, migrating around the head of the Anabara, Olenyok, Khatanga and Kotuy rivers, being originally from one of the central districts of today's Yakutia.

It should be recognised that the Chordu clan, known as the smallest clan about to go extinct, managed to survive to our days in the Village of Yessei and even to grow in number, by preserving its local identity as the Yakut clan of Chordu, coding the history of their past in legends, stories and myths.

The clan of Ospok - the name of Espek. In the materials of the historian B.O. Dolgikh, Yessei Espeks considered "a certain Petr Espek" that was a resident of the Dyupsyunsky ulus, invited to Yessei by earlier settlers as "a lawful person" to be their ancestor. The circumpolar census of 1926-1927 identified Espeks in a number of territorial groups of the western part of the region; there were 29 families (165 people) with 623 deer (Dolgikh, 1946: 260-261). These materials correlate with the family stories of the well-known old-timer of the Yessei village Vladimir Sidorovich Espek (Myrchyy or Myrsyy, which was his name in childhood) (1935-2018), and Espek Sidor Semenovich, the son of the informant B.O. Dolgikh (information was taken from the archive of the Krasnoyarsk Museum of Ethnography) V.S.). "The Espek (Ospok) clan originates from the same-name village Ospok in Yakutia. However, he remembers that his father S.S.
Espek told him that the Espek clan roamed in the upper reaches of the Olenek and Moyero rivers. He mentions that Knyaz Peter, a man who knew the law, was brought from Vilyuisk. In Vilyuisk, Peter married a certain bright field woman with 'Russian blood' and Espeks came from them." The old-timer identifies the ethnonym of the word Espek with the samename village located in the Dyupsyunsky ulus in Yakutia (now Ust-Aldan district). As for the differences in the origin of the Espek clan from Vilyuisk, or from the settlement of Ospek of the Dyupsyunsky ulus, V.S. Espek explained it very simply, "To get to Lake Yessei, you had to first get to Vilyuisk, then to the Olenek, and from there you could only get to Lake Yessei, so people settled in these places for various reasons, then wandered back and forth."

The younger generation, in a slightly different way, expounds their version of the Espek clan. Yuri Innokentievich Espek says that their paternal ancestors of the Espek clan "... from the year one during wanderings, coming to the vicinity of the lake or further to the mouth of the Moyero, in the area of Billeekh alyyt, or Taimenev Cape, discovered old decayed wrecks of chums with the remains of people inside and completely rotten wooden utensils. There were apparently from two to five chums of that kind. But our ancestors of the Espek clan were afraid to touch them, since it was a great sin - "anyy" yonna "anyyyr 5aan tuo 5 u daa tyytya huokhtaakhtar" (sin, superstitious ban, taboo), tried to avoid such places, being afraid of incurring misfortunes. They settled away, although the location of other abandoned camps was more convenient, close to water, to dry trees for using firewood." According to the informant, the remains of the people did not belong to the Yakuts.

Apparently, the abandoned camps belonged to the beginning and the first half of the $17^{\text {th }}$ century, when these areas were covered by the smallpox epidemic and might have belonged to the Tungus tribes of the Vanyads or Sinigirs. "My Espek ancestors wandered at the mouth of the Moyero River, the Olenek, and then wandered to the Vilyui, as the old people

\footnotetext{
Author's field data. Espek V.S. 1935 - 2018. Information dated July 2014. Yessei village.
} 
told."6 The corpus of various sources, which includes archival data, literary sources, scientific research, folklore materials and stories of modern informants, who are representatives of the clan and the Espek's name, allows us to make the following conclusion that the Espek clan originates from Central Yakutia, namely from the same-name village Ospek, located in the Ust-Aldan ulus.

The clan of Osogostok - the name of Osogostok in modern times in Yessei is numerous, they clearly position themselves as a sub-ethnic association of the Yessei Yakuts. According to the memoirs of Evdokia Filippovna Osogostok, a connoisseur of the Yessei folklore, their family originates from the Yakuts, "... from a fugitive Yeley, who seemed to have married without permission to the daughter of some Yakut ruler and escaped after that. Then he or his descendants appeared near the Yessei." 7 The Osogostok clan became known among northern Yakut reindeer herders only in the middle of the $19^{\text {th }}$ century. According to the materials of I. Lindenau, the beginning of the Osogostok clan was laid by a certain fugitive named Yersogostok or, as he was called Yeley, who married Omogoya, a pupil of one of Yakuts' ancestors (Lindenau, 1983: 79).

The transfer of the historical memory of the Sakha people about the legendary ancestors Omogoya and Yeley is projected onto the local myth of the northern Yakut reindeer herders. The general genealogical myth of the Yakuts is transformed in the memoirs of the inhabitants of the Yessei, for example, the name of the Osogostok clan is related to the name of Yeley that is Yersogostok (after Lindenau).

One of the legends about the origin of the Osogostok clan is associated with the old man Katygin. "An old man and an old woman settled near the Olenek River; the fact where they were born is unknown. The name of the old man is Katygin. They had a daughter. One guy came from the side of Bulun and found the old men and their daughter. Their daughter became pregnant from this guy. The old woman

\footnotetext{
6 Author's field data. Espek Yu.I. Born in 1955 Information dated July 2009. Yessei village.

7 Author's field data. Osogostok E.F. Born in 1930. Information dated July 2009. Yessei village.
}

informed the old man about the pregnancy of their daughter, 'Our daughter Oho5ostookh is (pregnant).' This woman gave birth to a son and named him Oho5ostookh (Osogostok). The Osogostok clan came from this child." 8

According to the 1897 census, the Osogostoks were represented by several branches of this clan and naslegs, among the Tungus and Yakuts of the North-West (Patkanov, 1906: 125).

In 1920-1930, representatives of the Osogostok clan were mentioned almost throughout the entire region of the Vilyui, Lena, Olenek, Popigay, Khatanga rivers, Lake Yessei, Kirbey, etc.; archival materials show that the total number of the Osogostok clan was about 1000 people?.

Some of the north-western representatives of the Osogostok clan had the name of Katyginsky or Khatygin (Dolgikh, 1946: 459-570), which is a direct confirmation of their administrative affiliation with the Khatyginsky administrative nasleg. In the village of Yessei only one family has survived so far, which had the name of Katyginsky, having roots from Yessei. In the mid-20 $0^{\text {th }}$ century, Nikon Katyginsky and his family returned back from Taimyr to Yessei. His son named Aleksandr Katyginsky married a representative of the name of Osogostok. No representatives of the name of Khatygyn could be found in the $19^{\text {th }}$ century. Even though at the beginning of the $20^{\text {th }}$ century the Katygin clan almost fully migrated from Yessei to Taimyr, and the representatives of the Katyginsky - Khatygyn name could not be found in Yessei since the 30 -ies of the $20^{\text {th }}$ century, this in no way speaks of their non-Yessei origin.

Of course, there are many versions about the origin of the Osogostok clan. B.O. Dolgikh identified the Osogostok clan with the Tungus tribe of Vonyadyrs - Vanyads, who had previously lived in the environs of Lake Yessei (Dolgikh, 1946: 90).

Since the Khatygin clan is directly related to the clan names of Yessei Yakuts, let us dwell on the origin of this clan.

\footnotetext{
8 Author's field data. Osogostok E.F. Born in 1930. Information dated July 2009. Yessei village.

9 Central State Archive of the Republic of Sakha (Yakutia). F.50. D.1459. L.28-290.
} 
The Khatygin clan was one of the largest clans among the northern Yakuts reindeer herders. The Khatygins constituted the bulk of these Yakuts on the lower Lena, forming four Khataginsky naslegs in the $19^{\text {th }}$ century - beginning of the $20^{\text {th }}$ century. The Khatygins moved to the lower Lena in the second half of the $17^{\text {th }}$ century from the middle Aldan, where they had previously formed the Katalinskaya or Khatylinskaya Yasachnaya volost. It must be assumed that the inhabitants of this volost, assimilated by the Yakut ethnos, are representatives of the Tungus tribes of the Khataginsky clan. As is known, the Tungus cattle breeders of the $17^{\text {th }}$ century in Southern Transbaikalia considered "Transbaikal Khatagins to be Mungal natives" (Dolgikh, 1960: 315-319).

As a result of their widespread settlement, the Khatygins appeared in the $19^{\text {th }}$ and early $20^{\text {th }}$ centuries on a large territory, both to the west and east of the Lena. "The Khatagins of the North-West totalled 812 people in 1897" (Patkanov, 1906: 167).

According to the census of 1926-1927, the number of Khatygins, taking into account all the units assigned to them, was 1205 people. The Khatagins as an administrative clan included the clans of Botulu, Espek, Maimaga, Osogostok and Uodai (Odai) (Dolgikh, 1950: 171). The Khatygins lived along the Anabar, the Olenek, and the Yessei.

The Espek informant Egor Ivanovich, referring to the story of his father, noted, "So, the Khatygins in the Yakut Yessei transcription of Haatyynkalar (should not to be identified with the naming unit "valenki" in plural in Russian - the author's note by K.E.). Дьэһиэйгэ - in Yessei, hотору буолла, һоччо да биллибэт буолбуттара, то5о дьиэтэххэ итинник киһилэр власть турар эрдэБинэ бары Дьэһиэйтэн Тоймуорга барбыттара, күрээбиттэрэ. Онтон биирдэрэ төннөн кэлбитэ hотору буолла. As I remember, in Yessei such names were not widely disseminated, I know that during the formation of Soviet power all the Yessei Khatygins left for Taimyr and settled there, later only one of the Khatygins returned, but he is a Yessei native. They even said that the Espeks and the Maimagi seemed to have relatives among the Khatygins, but I don't know it for sure, I heard it from my grandmother." 10

We had a chance to collect information from the current representatives of the surname Katyginsky, so Alexander Katynsky shared a legend he heard from his father: "Катьгиннар - биһиги, урут хоһууннар, Өлөөн төрдө биһиги - hereinafter a pun биир киһи хоһуун - а pun" (literary translation by K.E.: "Khatygyn is our family, it comes from Khatygin, who was a famous bogatyr warrior khosun and had ancestors in Olenek. My parents were born in Yessei, but left for Taimyr in Khatanga, but the parents are from Olenek. " The informant focuses on the fact that he does not associate himself with Taimyr Yakuts and Dolgans. Old people remember the Yessei origin of this surname.

Representatives of the surname Osogostok, who used to be a part of Katygin nasleg and had common ancestors with the representatives of the Khatygin-Katyginsky family line, were connected by common Yakut origins in the recent historical past.

Botulu family - surname Botulu. According to the 2010 census in the Evenki municipal district of Krasnoyarsk Krai, Botulu is currently one of the most numerous surnames in modern settlement Yessei.

According to Ya.I. Lindenau, Боотур yyha family was previously known as Khatyly, and Khatan Khatamallai, the son of Ellei, who is considered to be their ancestor (Lindenau, 1983: 21). Ya.I. Lindenau also noted that legendary Omogoy (Omogon) was from the Batulu family ${ }^{12}$.

It is noteworthy that there are still partial or complete parallels of Yessei generic names in the territory of Yakutia. As for the name of the Botulu family, according to 1893 statistics in the Yakutsk region, there were Botulinsky naslegs in the Zhigansky, Ust'-Yansky and Verkhnevilyuysky districts ${ }^{13}$.

\footnotetext{
${ }^{10}$ Author's field data. Espek E.I. 1934 - 2016. Information dated August 2006. Yessei village.

${ }^{11}$ Field data of the author. A.N. Katyginsky, year of birth 1945. Information of April 2018, Yessei settlement.

12 Archive of SB RAS. F. 5. S. 1. C. 151. P. 94.

${ }_{13}$ Volosts and Settlements of 1893. SPb, TsChK MVD Publishing House, 1894, 9, Yakutskaya Oblast, 1894, 8-9.
} 
According to the research by S. Patkanov, 205 representatives of the Botulinsky family are listed in Kil'demsky nasleg of West Kangalassky ulus (Patkanov, 1912: 718-735).

B.O. Dolgikh wrote that "in 1926-1927, there were 279 representatives of the Botulu family in the western part of the region" (Dolgikh, 1946: 118).

It is interesting to note that representatives of the Botulu family or the Batulintsy could be found among the reindeer herders of Vilyuy and northern Yakutia. However, it is believed that they moved to the outskirts of Yakutia, fleeing from yasak tyranny. "The name "Боотулу" is recorded among the Vilyuy, Olenek, Zhigansky and Ust'-Yansky groups of Sakha" (Vasil'ev, 1986: 31). (Reference to the word "Batulintsy" (боотулу, баатылы) - families of Vilyuy and northern Yakuts).

Representatives of the Khataginsky family Botulu can be considered the descendants of the Batulinskaya volost of the $17^{\text {th }}$ century Yakut settlement that was on the right tributaries of the Aldan, Amga and Tatta rivers. Folk etymology produces the ethnonym Botulu from the corresponding term - a word denoting a pole for tying horses (the information obtained from the Yakuts living in Suntarsky district of Yakutia).

Current representatives of the Botulu family identify themselves with the descendants from Vilyuy ulus of Yakutia, believing that their ancestors came to Yessei from that place.

Evdokia Petrovna Chordu, the Yessei folklore expert, told the legend about the Botulu family appearance on the Yessei land in the following way: "People did not come to settle near Yessei on purpose, they were driven by hardships. This place was rich in game, fish and wild deer. An old man named Bootuluu was the first of the Botulu family who came here with his wife and son, and they started their family. ${ }^{14}$ ",

According to the story of Aleksey Yakovlevich Botulu "The ancestors of the surname Botulu came to Yessei as reindeer herders from Vilyuysk, located in neighbouring Yakutia but, at the same time, a part of the Botulu family no-

\footnotetext{
${ }^{14}$ Field data of the author. E.P. Chordu, 1926-2016. Information of July 2009, Yessei settlement.
}

madised around Olenek and even went to Khatanga. Our family Botulu comes from the old man Bootuluu. That was, probably, his name. He came to Yessei from Olenek in search of good hunting grounds and pastures for deer, and having come here, he stayed here with his family and gave origin to our family and surname. ${ }^{15}$ " Herewith, all the categories of the respondents deny their Tungus origin, considering themselves to be Yakuts.

Vladimir Sidorovich Espek said: "According to my mother's stories, the Botulu family comes from people who left Yakutia and permanently settled on Lake Yessei two or three generations ago. This is how Botulu used to nomadise from Olenek to Yessei, and then to Kirbey. But, of course, they spent winter in Yessei. Then they permanently settled on the lake and nomadised to different places from Yessei. The fact that they come from Yakutia is verified, since, as I recall, the old people from their family said that they were from Vilyuy ${ }^{16 "}$

The above gives an opportunity to conclude that representatives of the Botulu family came here in the $19^{\text {th }}$ century from Vilyuysk and joined the ethnographic group of northern Yakut reindeer herders who nomadised in the upper reaches of the Olenek, Anabara, Kotuy and Khatanga rivers.

Historic landscape. The Maimaga family or the surname Maimaga in modern Yessei, in the old transcription "Maimattsky Маймаца," was listed in the central regions of present-day Yakutia since the late $18^{\text {th }}$ century. There were 7 persons who paid yasak tax. This family was later listed in Namsky district (Dolgikh, 1960: 373-374).

In the middle of the $19^{\text {th }}$ century, representatives of the Maimaga family appeared near lake Yessei. According to archival materials, Yakut Maimaga from "Botulu-Katygynsky nasleg" is listed in the parish register of the Turukhansk monastery for $1885^{17}$.

According to a later census of the region's population, the 1926-1927 Circumpolar cen-

\footnotetext{
${ }^{15}$ Field data of the author. A.Ya. Botulu, 1935-2005. Information of August 1998, Buordaakh area, Yessei settlement.

${ }^{16}$ Field data of the author. V.S. Espek, 1935 - 2018. Information of July 2014, Yessei settlement.

${ }_{17}$ Evenki archive of Krasnoyarsk krai. F.30. S 1. C.78. P. 23.
} 
sus, there were 6 families of the Maimaga family representatives, 41 people (Dolgikh, 1946: 443-548), while administratively the Maimaga family representatives belonged to the Khataginsky nasleg.

"According to old men's stories, the Maimaga family used to have a lot of deer, they were generally fair people with white skin and blond hair, and their ancestors came to Yessei from Vilyuy two generations ago. They immediately started herding deer and got what they wanted. ${ }^{18 \text { " }}$

Most likely, the origin of the Maimaga family should be searched for in the similarly named village Maimaga, currently located in Namsky district of the Republic of Sakha (Yakutia). The name of the family here was transformed into the name of the village in Yakutia, and the name of the family in Yessei was transformed into the surname.

In this way, representatives of the Maimaga family came to the vicinity of the lake as an established family of the northern Yakut reindeer herders, who were mixed with other ethnic groups in the past, but with a clear self-awareness of their Yakut origin, that is, as Yakuts of the Maimaga family who migrated to lake Yessei in the past.

The Beti family (Betu) - in modern Yessei is it surname Beti. Representatives of this surname migrated to Taimyr from Yessei, where the name of the family were transformed into surname Bettu, apparently, taking into account local lexical features. In this way, according to archival data, in the $19^{\text {th }}$ and early $20^{\text {th }}$ century the Beti family was purely of administrative nature, but originated from the ancestral group of Betiltsy - people from the Betunkaya volost of Yakutia, which was on the right bank of the Lena River near the mouth of the Aldan river. "The Betunkaya volost, and the beginning of its disintegration, can be related to the uprising of its inhabitants against the yasak yoke, which started in 1636-1637 and finished in 1642 , when the Yakut "appointed head" Vasily Poyarkov defeated the fortified dungeon of Prince Kamyk, where about 300 armed Yakuts were hiding" (Miller, 1961: 1554-1157). After

\footnotetext{
${ }^{18}$ Field data of the author. E.P. Chordu, 1926-2017. Information of July 2009, Yessei settlement.
}

the defeat, the migration flows of the Betuntsy headed mainly up the Aldan river, down the Lena river and up the Vilyuy river. Local Tunguses started mentioning the Beti (Betilsky) family on the lower Lena in the late $17^{\text {th }}$ century. According to S.I. Gurvich "Ethnically heterogeneous origin of this family is specified by the presence of Yakut and Tungus names" (Gurvich, 1966: 86-87). According to historical legends, a person with a Yakut name "Кэтит Туут Улуңнаах" was a founder of the Betilsky family. The archival material about the fact that in 1732 Yakut "Betiunsky" family was listed on the Vilyuy river, at the Ust-Vilyuy winter place, is equally important ${ }^{19}$. And again, based on archival data and literary sources, it can be determined that representatives of the Beti family (at that period they were called the Betiltsy family) started moving west from the lower Lena in the middle of the $17^{\text {th }}-18^{\text {th }}$ centuries. In the late $18^{\text {th }}$ century there were several administrative families of Betiltsy in the North-West of Yakutia, and information about them was recorded in archival data of that period.

In 1858-1859 there were 202 people from the Betilsky family in Vilyuysky district, in 1897 they were not recorded there, but the same family appeared in Turukhansk Krai in 1897. In 1898-1859 there were 505 representatives of another family - Betiulsky in Vilyuysky district, but in 1897 there were no representatives of this family in Vilyuysky district. There were 385 representatives of the family named Betinsky in 1897 in Vilyuysky district, although there is no information about the Betinsky family in Vilyuysky district in 1898-1859. 48 representatives of the same Betinsky family appeared in Turukhansk Krai in 1897.

Taking into account such difference in the number of the Betiltsy family representatives, S.K. Patkanov suggested that "During the 1858-1859 census the Tunguses of the Chordun family, which was never mentioned as an independent ethnonymic unit, were included into the family." B.O. Dolgikh recorded 939 people with other Betiltsy of the region with all kin groups (Dolgikh, 1950: 171); he included western groups of the Chordu family, as well as

\footnotetext{
${ }^{19}$ Central state archive of RS (Y). F. 199. S. 1. C. 4814.7. P. 221.
} 
related small groups such as Motodur, Uriunei and Beti (Betu) into the family (Dolgikh, 1946: 443-548).

Due to the dramatic changes in the migration routes of a wild reindeer and other hardships in hunting and economic activities, the population of the Zhigansky district experienced a number of brutal hunger strikes. I.S. Gurvich noted: "Disasters took place in 1799-1803, 1805-1806, 1812, 1814, 1816-1818" (Gurvich, 1966: 164-166). Members of the Betil family, especially those suffering from hunger, transferred to the department of the Upper Vilyui District. Several of their families migrated to Turukhansk district. According to I.S. Gurvich, "A significant part of the families of the Khatalinsky nasleg and the Betyun family who wandered around Olenek and visited Lake Yessei was transferred to the Vilyui district. The Northwest in these years has ceased to attract new settlers. Nevertheless, according to the revision of 1816 , there were 2,423 people in the Zhigansky District in the Northwest, the subsequent census of 1830 showed that the population was reduced by 92 people. However, during these years the Vilyui reindeer herders, the Betiltsy, Betyuntsy, Khatagintsy, began to enter the territory of the Zhigansky ulus. Considering these groups, at least three thousand people reclaimed the Northwest of Yakutia" (Gurvich, 1966: 166-167). (Reference to the word "Betyuntsy" - large tribal units in the Namsky and Amginsky (formerly Botrussky) uluses).

According to I.S. Gurvich, "In the documents of that time, the population of the Khatyginsky nasleg, such families as Osogostok, Chordu, Espek, Beti, Khatigyn, etc. were designated as wandering Tungus, but with the Yakut language, although they considered themselves, according to genealogical traditions, as Yakuts. It is not surprising that the official authorities of those times, without particularly delving into ethnic characteristics, equated all "vagrant" families with the Tungus ones considering the way of their economic activities" (Gurvich, 1977: 23-24). It should be noted that in the Olenek and Anabar regions the term "Tungus", "Evenki" did not denote ethnicity, but a way of life.
Therefore, most genealogical traditions of the past and the present identify the founders of families with the northern Yakut reindeer herders who reclaimed the river basins of Olenek and Anabar, Lower Lena, and who came from the central uluses. Only the family Beti was recognised by many informants as Evenki-Yakut.

As the scientific ethnographer Boris O. Dolgikh rightly noted, the Yessei Yakuts were not descendants of the population of the Yessei volost of the $17^{\text {th }}$ century, but were Yakut reindeer herders who entered the region of Lake Yessei from the Olenek river basin. Genealogical traditions of the Yessei Yakuts eloquently speak about this. Olenek once belonged to the Vilyui volost and there, they were recognised as the "Vilyui Tungus", but they considered themselves as the Yakuts. The Yessei Yakuts were part of the Betunsky, Katyginsky and Betilsky naslegs and were divided into families. According to sources, such families as Botulu, Osogostok, Espek and Maimaga were in the Katyginsky nasleg, the Chordu family was in the Betunsky nasleg, and the Mayat family was in the Betilsky nasleg.

The Yessei Yakuts, as an ethno-local group of polar Yakuts-reindeer herders formed as a result of the administrative-territorial division at the beginning of the $20^{\text {th }}$ century, having found themselves in ethno-social isolation, retained the archaic language, Yakut folklore and the blood-related structure of their group. Passing their genealogical narratives appealing to the historical past of the Yakuts from generation to generation, the Yessei thus established their ethnic identity.

The borders of memory: movement as a continuous life cycle. Prior to the establishment of modern administrative-territorial boundaries, the area of Lake Yessei, or as mentioned in Tsarist time, the "Zhessey district" was administratively subordinate to the Vilyui district of the Yakutsk region. According to the recollections of residents of the village of Yessei, the Yessei Yakuts often travelled to Vilyuisk "to pay yasak and buy the necessary goods." Their family leaders constantly lived there, and

${ }^{20}$ Central State Archive of the Republic of Sakha (Yakutia). F. 23. Op. 1. D. 3085. L. 1. 
they constantly kept in touch with them. According to R.K. Maak, "People travelled from Lake Zhessey to Vilyuisk in 18 days... Merchants and prosperous Yakuts also travelled from Vilyuisk and from the okrug to Zhessey for trade riding deer in winter and horses in summer" (Maak, 1886: 120).

Movement as an adaptation mechanism in preserving the ethno-local group of the Yessei Yakuts as a social organism is translated in the activity scenarios the modern Yessei.

To date, many residents of Yessei have blood relatives in the village of Olenek. According to the stories of the old residents of Yessei, the Yessei Yakuts maintained close family ties until the establishment of administrative boundaries in 1930 of the $20^{\text {th }}$ century, which then gradually came to naught due to objective factors, but individual family ties were not cut off even in the 1990's. The informant M.Kh. Espek made some examples of the immigrants from the Oleneksky district who had family ties with the Yessei Yakuts. Thus, "doctor Eduard Semenov lived in the village of Kharyalakh of the Oleneksky district until the end of the 90's of the $20^{\text {th }}$ century. He came to the village of Yessei in 1988 with a delegation from Olenek. He told what comes from the Espec family and was a blood relative of the Espec brothers Christopher Ivanovich, Ilya Ivanovich, Vasily Ivanovich and their sister Akulina Ivanovna, who lived their entire conscious lives in the village of Yessei in the $20^{\text {th }}$ century. In addition, during the formation of Soviet power, two more sisters of the above-mentioned relatives left Yessei, one to Taimyr, the other to Olenek, and later, unfortunately, family ties were lost."'2l "A native of the Oleneksky district of the village of Kharyalakh, Maryana Dmitrievna Sleptsova, born in 1974, her ancestors were descended from the Osogostok family."'22

We have to admit that at the present stage, the ties of the Yessei Yakuts with the metropolis - the Republic of Sakha, are limited to single family ties or spontaneous administrative attempts to establish interregional ties at

\footnotetext{
21 PMA. Espek M.Kh. Born in 1941. Information from July, 2015. Yessei.

22 PMA. Chordu (Osogostok) A.N. Born in 1973. Information from June, 2018. Yessei.
}

the level of municipal district authorities, both from the administration of the Evenki municipal district of the Krasnoyarsk Territory and the administrations of uluses - districts of the Republic of Sakha (Yakutia).

There are no public organizations or associations developing such relations between the Yessei Yakuts and the Yakuts from the Republic, although attempts to establish ties have been repeatedly made.

Thus, a former deputy of the Evenk Legislative Assembly (Suglan), and after the reorganization of the Evenk Autonomous Okrug into the Evenk Municipal District of the Krasnoyarsk Territory in 2007 a deputy of the district council of deputies of the administration of the Evenk Municipal District of the Krasnoyarsk Territory Gennady Nikolayevich Maimaga, from the beginning of the 2000's, attempts to organise inter-regional relations between the Republic of Sakha (Yakutia) and the Evenk Autonomous Okrug, then the Evenk Municipal District as part of the Krasnoyarsk Territory, but, unfortunately, for objective reasons, there are no strong and permanent ties fixed by any regulatory documents so far.

It is another thing when the question comes to the family-social relations of the Yessei Yakuts with the Olenek Yakuts, conditioned by the financial and economic reasons.

Starting from 2016, representatives of the Osogostok family from the village of Yessei began to establish such ties themselves, namely an individual entrepreneur, a deputy of the rural settlement of Yessei, Alexander Nikolaevich Osogostok, born in 1968, paved the road on snowmobiles from the village of Yessei to the village of Olenek (the distance between the settlements is $670 \mathrm{~km}$ ).

Such ties are still of an economic nature, the Yessei hunters from the Osogostok family deliver hunting products and wild reindeer meat to the village of Olenek.

In 2018, a deputy of the rural settlement of Yessei, Alexander Nikolayevich Osogostok made a proposal to the district council of deputies of the Evenki Municipal District of the Krasnoyarsk Territory on the legal consolidation of economic and cultural ties between the Evenki Municipal District and the Republic 
of Sakha (Yakutia). At this stage, at the level of municipal authorities, the issue of acquiring domestic deer in the Republic of Sakha (Yakutia) for the revival of domestic reindeer husbandry in the village of Yessei is being decided upon an initiative of the deputy A. Osogostok.

At present, the Yessei Yakut from the Osogostok family Alexander Nikolaevich Osogostok initiated the revival of the family community of the Osogostok family at the level of the district council of deputies of the Evenki Municipal District, the main emphasis of which, of course, will be aimed at strengthening interregional ties between the Yessei Yakuts living in Evenki district of the Krasnoyarsk Territory and the Republic of Sakha (Yakutia).

"Биһиги - Дьэһиэй һахалара төрдубутун ойдуу hаныль hылдьабыт, хантан кэльбиппитин, хаһан бу дойдуга олохсуйбуппутун. Мин Оho5ocmoox фамилиятыгар киирэбин, бэйэм Оhо5остоохпун, бу дойдуга бу һиргэ төрөөбутум-Үөскээбитим, улааппытым, мин төрдҮлэрим, өккөннө мин о5олорум эмиэ бу һиртэн төрдҮҮлээхтэр, ол да буоллар биһиги о5олуун-кырдьа5астыьын төрдубҮтҮн, тылбытын умнубаппыт, hҮтэрбэппит. Билигин бу Үйэ5э барыта hYтэ турда5ынан, о5олорбут инникилэрин һанаан, биһиги Дьэһиэй һахалара һаха Республикатын кытта һокуону тутуһан связьпытын һанатыттан һа5алаан, hYтэрбэтэхпитинэн haтанар" (literal translation by K.E. - "We, the Yessei Yakuts, do not forget the historical roots, where we came from, and how our ancestors settled here. I belong to the Osogostok family, I was born and raised here, on this land, my ancestors and my children are also immigrants from this land, but nevertheless, weather it is old people or small children - all of us perfectly remember our historical roots, and do not forget our native Yakut language. Now is the time of global changes, when many nationalities are losing their national roots and traditions, language and culture, but we, the Yessei Yakut people, must not forget about the future of our children, our future, and therefore, we must revive and renew cultural ties with the Republic of Sakha (Yakutia)"). ${ }^{23}$

In the context of the cultural memory of the Yakut reindeer herders Lake Yessei has the following meanings: "culture of remembrance", symbol and ritual. One of the important adaptive mechanisms of local identity creation is cultural memory. If we touch upon the mental map of the Yessei Yakuts we will be able to distinguish its central image, namely Lake Yessei, which is the main life locus forming the sacred world of the living near the lake Yakut ethnic group. This ritual code of the Yessei Yakut is realised, for example, in the ancient song "Sippie" dedicated to the spirit of the mistress of Lake Yessei and recorded in 1938 by ethnographer and folklorist A.A. Savvin who witnessed its performance by S.A. Zverev-Kyyl Uol, the folk singer, a connoisseur of Yakut traditions. The plot of the song consists of: 1 . The girl's recollection of happy and carefree life by the lake, where she was born and lived with her family. It is an autobiographical story of a girl called "Moibordookh Matryona" (Matryona with a "white stripe around her neck" (i.e. white wool)). She was the daughter of a prince, had eight sisters and one brother. She never left the house, nor she was exposed to the sun, so she was a "virgin" girl and a bride. 2. The attack on this girl's kin and family by foreign warriors with spears, the death of her relatives and the ruin of the family estate. In this part there are frequent ancient formulas: "They put out the fire of the hearth and scattered the ashes of their relatives. 3. Parting with the lake as if with a mother's womb; the lake here acts as a place of tribal memory. Appeal to the lake, its praise as a symbol of happiness, integrity and perfection. "Neither in the Upper World, nor in the Middle World, and even where the sun sets, I have never seen better than you, Grandma D'esei"'24. Semantically, the verbal text forms a constructive model of the uniting (through the image of a lake) and disuniting movements (invasion of strangers, ruin and death). In this case, "word" and "action" are close to tradi-

\footnotetext{
${ }^{23}$ PMA. Osogostok A.N. Born in 1968. Information from June, 2017. Yessei.

${ }^{24}$ Archive of Yakutsk Science Centre of SB RAS. File 5. List 6. D. 30 . P. $170-174$.
} 
tion of making spells. For instance, the central character of the song is the lake itself with which the girl talks. The symbols of happy and rich life of the Yakuts are presented through the image of the lake: the lake is abound in fish and game and is surrounded by a dense forest, replete with valuable animals, and the girl's family lives together by the lake. The very title of the song "Sippie" is sacral and correlated with the verb "sipsii" - cf. "sip", Buryat "shipshi" - to whisper, to speak; (Dictionary of the Yakut language, 2008: 2235). The basis of the verb "sippie" is archaic, O.N. Betling gives numerous examples of the bases ending with the diphthong [ia] in his works (Betling, 1990: 308.) The semantic organization of the song as a text implies a magical context, the verb "sippie" (meaning "to whisper") concentrates in itself the semantics of the ritual action and acts as its semantic origin. According to mythological notions of the Yakuts, it was forbidden to utter the real name of the lake, doing this was considered a great sin. The semantic structure of the olden song includes ritual repetitions of the name of the action - "sippie" ("to whisper") before and after pronouncing the name of the lake "D'esei, D'esei ebekem" ("My Grandma, D'esei"), which can be explained by the multiple layers in the mythological situation. Whisper as a form of speech behavior and a part of the traditional worldview of the Yessei Yakuts was closely connected with the ritual symbolism (word - ritual action - charm). The pronunciation of the word "sippie" was accompanied by an initial deep breath (2 times), after which the word itself was pronounced twice $^{25}$. The song-remembrance devoted to the lake displays archaic "genres" of the traditional Yakut culture: bygone vocabulary, beliefs, ancient forms of praising the lake and addressing the lake as a living creature in the form of Yakut "algys" (creation), on the other hand, events related to the invasion of strangers and the death of relatives are described in the form of curses - "kyryys" (destruction). The ring song composition is created by encoding the image of the lake as a cultural sign at the beginning and end of the verbal text.

25 Archive of Yakutsk Science Centre of SB RAS. File 5. List 6. D. 30. P. 173.
Addressing the lake at the end as a symbol of harmony and perfection implicitly brings us back to the mythological theme of birth death - birth. It is worth mentioning that this is the only variant of the song "Sippie" in the collection of oral archaic Yakut texts. At the same time, ethnographer A.A. Savvin recorded valuable additions to the song, performed by the folk singer Sergei Zverev, who visited Yessei during his wanderings in the times of his discipleship as a sacral singer, storyteller and shaman. What it involves is a legend that once there were 7 birch-bark buildings (urasa) near the lake, where the Yakuts lived, and later they were killed by the Tungus people. Only one 16-year-old girl, a stutterer, escaped to the Viliui Yakuts. That is when she sang that song, the old men told ${ }^{26}$. In this case, the image of the only girl who survived is of particular interest. Moreover, the fact that she is endowed with such a blemish as stuttering demonstrates the girl's otherness and points to the connection between this image and shamanic mythology. The earlier researcher E.S. Novik also noted that the stuttering is connected with its function of a mediator-translator between people and spirits of a higher rank (Novik, 1964: 79-81). This idea can also be traced to Yakut shamanism, where the shaman's assistant, Keleeni, a limping stutter, appears; he comes during the shamanic summoning the spirits and communicates with the participants of the ritual action. In this respect, the comparison of sacral and real texts reveals a similar structure. All this allows us to highlight the shamanic "layer" of the analysed song.

Thus, the ancient Yessei Yakut song dedicated to Lake Yessei is a dialogue between Nature and Man related to the ritual of reproducing the birth of a new world (addressing Lake Yessei as the image of Macrocosm), where in the image of the lake and by naming all the elements of Micro and Macrocosm Nature grants a resource for recreating the happy life of the Yessei Yakuts.

The ritual of giving gifts or sacred offerings to water - the lake still exists today, while the attitude of the modern youth of the Yessei

26 Archive of Yakutsk Science Centre of SB RAS. File 5. List 6. D. 30. P. 173-174. 
Yakuts to such actions is purely individual, the perception of the lake as a part of the living space shows an undoubted share of sacralization (conversation of hunters and fishermen, different people after a long absence from their homeland with the lake, etc.) and attributes the image of Lake Yessei to the history of the past, when the lake fulfilled a unifying and creative function.

\section{Conclusion}

Living in another national and regional subject did not lead the Yesei Yakuts to losing their identity, but on the contrary this fact united this sub-ethnos; such unity and solidarity at the territorial level (life by the lake), manifested both in the ethno-cultural and socio-economic space, bound the Yessei Yakuts into a single organism. The feeling of the Yessei Yakuts of their ethnic identity as belonging to the Yakut ethnos is expressed by the following factorrs: 1) awareness of their national unity on the sub-ethnic level; 2) common historical past and blood ties with the main Yakut ethnos whose representatives live in the adjacent region; 3) "culture of recollections" as a resource of collective identity maintenance; 4) unity and similarity of ethnic and cultural interests, community of one historical destiny.

In an era of globalisation and the loss of ethnic and cultural heritage, the collective memory of the Yesseis began to play a therapeutic role. Demonstration of their identity as sense of belonging to the Yakut ethnos through the revival of the culture of recollections, the restoration of original ethnic traditions, connection with the kin landscape (Yakutia) and the preservation of their mother tongue became an essential part of the national project started by the Yessei intelligentsia.

\section{References}

Betlingk, O.N. (1990). O iazyke iakutov [On the language of the Yakuts]. Novosibirsk, "Nauka", 646 p.

Dolgikh, B.O. (1946). O naselenii basseinov rek Oleniok i Anabary [On the population along the banks of the Olenyok River and the Anabar River]. In Sovetskaia etnografiia [Soviet ethnography], 2, 90.

Dolgikh, B.O. (1946). O rodoplemennom sostave i rasprostranenii encev [On the kin-tribal composition and dispersal of the Enets people]. In Sovetskaia etnografiia [Soviet ethnography], 4, 459-570.

Dolgikh, B.O. (1950). K voprosu o naselenii basseina Oleneka i verkhov'ev Anabary [On the population in the basin of the Olenyok River and upper reaches of the Anabar River]. In Sovetskaia etnografiia [Soviet ethnography], 4, 171.

Dolgikh, B.O. (1960). Rodovoi i plemennoi sostav narodov Sibiri $v$ XVII veke [Kin and tribal composition of the Siberian population in the $17^{\text {th }}$ century]. Moscow, Publishing House of Academy of Science SSSR, $620 \mathrm{p}$.

Golovnev, A.V. (2009). Antropologiia dvizheniia (drevnosti Severnoi Azii) [Anthropology of movement (antiquitites)]. Yekaterinburg, UB RAS, 496 p.

Gurvich, S.I. (1966). Etnicheskaya istoriya severo-vostoka Sibiri [Ethnic history of northeast Siberia]. Moscow: Nauka, 269 p.

Gurvich, S.I. (1977). Kul'tura severnykh yakutov-olenevodov: K voprosu o pozdnikh etapakh formirovaniya yakutskogo naroda [The culture of the northern Yakut reindeer herders: On the issue of the late stages of the formation of the Yakut people]. Moscow: Nauka, $247 \mathrm{p}$.

Ksenofontov, G.V. (1937). Uraangkhai-sakhalar: Ocherki po drevnei istorii iakutov [Uraangkhaisakkhalar: Reviews on the ancient history of the Yakuts], 1. Irkutsk, Publishing House of East Siberian Region, $576 \mathrm{p}$.

Lindenau, Ia.I. (1983). Opisanie narodov Sibiri (pervaia polovina XVIII veka): Istoriko-etnograficheskie materialy o narodah Sibiri i Severa-Vostoka [Description of the Siberian population: Historical and ethnographic materials on the peoples of Siberia and Northern East]. Magadan, Magadan Publishing House, $176 \mathrm{p}$.

Maak, R.K. (1886). Viliuiskii okrug Iakutskoi oblasti [Vilyuysk district of the Yakutsk Oblast'], 2. Saint-Petersburg, 504 p. 
Miller, G.F. (1961). Etnograficheskie rezul'taty Velikoi Severnoi ekspeditsii 1733-1743 gg. [Ethnographic results of the Great North expedition in 1733-1743], In Trudy Instituta etnografii im N.N. Mikluho-Maklaia. Sibirskii etnograficheskii sbornik [Proceedings of the Institute of Ethnography named after N.N. Miklouho-Maclay], 3. Moscow, Leningrad.

Novik, E.S. (1964). Obriad i fol'klor v sibirskom shamanizme [Ritual and folklore in Siberian shamanism]. Moscow, $304 \mathrm{p}$.

Patkanov, S.K. (1906). Opyt geografi i statistiki tungusskikh plemen Sibiri na osnovanii dannykh perepisi 1897 goda i drugikh istochnikov [Experience in geography and statistics of the Siberian Tungus tribes on the basis of census data of 1897 and other sources], 1, 2. Saint-Petersburg.

Patkanov, S.K. (1912). Statisticheskie dannye, pokazyvaiushchie plemennoi sostav naseleniia Sibiri, iazyk i rody inorodtsev (na osnovanii dannykh spetsial'noi razrabotki materiala perepisi $1897 \mathrm{~g}$.): $\mathrm{v} 3$ tomakh [Statistic data demonstrating tribal composition of the Siberian population, the language and kins of the non-Russians: in 3 vols.]. In Zapiski imperatorskogo Russkogo geograficheskogo obshchestva po otdeleniiu statistiki [Notes of the Imperial Russian geographical society. Department of Statistics]. Saint-Petersburg.

Slovar' yakutskogo yazyka: $v 3$ tomakh [Dictionary of the Yakut language: in 3 volumes] (2008). E.K. Pekarskiy (ed.). Rossiyskaya akad. nauk [the Russian Academy of Sciences. St. Petersburg: Nauka, Vol. 2. Release 5-9. 614 p.

Vasil'ev, Iu.I. (1986). Sposoby vyrazheniia sravneniia v iakutskom iazyke [Means of expressing comparison in the Yakut language]. Novosibirsk, "Nauka", 109 p.

\title{
Формирование субэтнической группы ессейских якутов: ландшафт, история, память
}

\section{Е.Н. Романова, Е.М. Кузнецова}

Институт гуманитарных исследований

и проблем малочисленных народов Севера СО РАН

Российская Федерация, Якутск

\begin{abstract}
Аннотация. Настоящая статья представляет формирование субэтнической группы якутов в исследовательской траектории: ландшафт, история, память и посвящена изучению периферийной этнолокальной группы ессейских якутов, компактно проживающих на озере Ессей Красноярского края с XVIII века. На основе полевых материалов реализованы методы опроса, картографирования, глубинного интервью, введены в научный оборот ранее не опубликованные архивные материалы, нарративные источники.
\end{abstract}

Ключевые слова: магистральные и локальные культуры, ессейские якуты, культурное пограничье, ландшафт, исторический контекст, континуум, помнящая культура.

Научная специальность: 07.00.07 — этнография, этнология и антропология. 